\title{
Host Modification of the Adherence Properties of Chlamydia trachomatis
}

\author{
By SUBIR K. BOSE* AND PRABHAT C. GOSWAMI \\ Department of Microbiology, St Louis University School of Medicine, \\ St Louis, Missouri 63104, USA
}

(Received 6 November 1985; revised 17 February 1986)

\begin{abstract}
The adherence of Chlamydia trachomatis LGV440(L1) to human HeLa 229 and mouse McCoy cells was stimulated by the lectin wheat germ agglutinin (WGA) and inhibited by the sugars $N$ acetyl-D-glucosamine, $N$-acetyl-D-galactosamine and chitobiose, but only when the chlamydiae had been passaged several times in HeLa cells. After passage in McCoy cells, the lectin and the sugars elicited little response. The non-LGV serovar UW-31(K), however, differed from LGV440(L1) in that, regardless of passage, the lectin and sugar effects were observed only in HeLa cells. Affinity chromatography on WGA-agarose confirmed that HeLa-grown LGV$440(\mathrm{~L} 1)$ bound to a significantly greater extent relative to McCoy-grown chlamydiae. In addition, participation of heterogeneous chlamydial ligands was suggested by the observation that the adherence of heated $\left(60^{\circ} \mathrm{C}, 5 \mathrm{~min}\right) \mathrm{UW}-31(\mathrm{~K})$ to HeLa cells at $37^{\circ} \mathrm{C}$ was not inhibited at all, but at $5{ }^{\circ} \mathrm{C}$, the adherence rate was greatly reduced, indicating the participation of heatstable as well as heat-labile ligands. These data are interpreted to indicate that the passage history of $C$. trachomatis results in the acquisition of altered surface components that participate in the initial interaction of the bacterium with the host.
\end{abstract}

\section{INTRODUCTION}

Chlamydiae are obligately parasitic bacteria responsible for a wide variety of animal and human diseases. The infectious spherical entity called the elementary body (EB) attaches to the host cell membrane, is internalized and subsequently undergoes a functional and morphological transition within the phagosome. Although obligately parasitic, the chlamydiae require centrifugation on to host monolayers for efficient infection in vitro. Few cell lines are known to be susceptible to productive infection by Chlamydia trachomatis, especially the nonlymphogranuloma venereum serovars. Therefore, most of the studies with the oculo-genital strains of $C$. trachomatis have involved the established human cell line HeLa 229 and the mousederived lines $\mathrm{L}$ and McCoy. Serial passage of chlamydiae did not reduce pathogenicity for animals (Jenkin, 1966) or for humans (Mitsui et al., 1967). Furthermore, it has been noted that successive passage in cell cultures resulted in an 'adaptation', i.e. rapid development of the intracellular bacterium, and also acquisition of greater infectivity to the cell cultures than when grown in chick yolk sac (Griffiths et al., 1976). However, during passage of the trachomaderived $C$. trachomatis strains in McCoy cell cultures, there was no detectable alteration in the major antigens (Gordon et al., 1971).

During our studies on the adherence characteristics of an oculo-genital serovar of $C$. trachomatis, we observed that the lectin wheat germ agglutinin (WGA) stimulated the unassisted adherence of purified EBs of $C$. trachomatis strain UW-31 to HeLa 229 monolayer cultures (Bose et al., 1983). We had previously noted that the adherence of two lymphogranuloma venereum (LGV) serovars, 434(L2) and 404(L3), to HeLa 229 was unaffected by this lectin. Furthermore,

Abbreviations: EB, elementary body; LGV, lymphogranuloma venereum; WGA, wheat germ agglutinin. 
the adherence of UW-31 but not of the two LGV serovars to HeLa 229 monolayer cultures was sensitive to $\mathrm{N}$-acetylglucosamine (GlcNAc), $\mathrm{N}$-acetylgalactosamine (GalNAc) and $\mathrm{N}$ acetylneuraminic acid (NeuNAc), suggesting that hexose-containing moieties on the host cell surface participated in this interaction (Bose et al., 1983).

In this study, we present data that show that the passage history of $C$. trachomatis affects adherence characteristics of the bacterium.

\section{METHODS}

Host cell lines and their cultivation. HeLa 229 was purchased from the American Type Culture Collection, Rockville, Md, and grown in Eagle's minimal essential medium (MEM), supplemented with non-essential amino acids, gentamicin $\left(50 \mu \mathrm{g} \mathrm{ml}^{-1}\right)$ and $5 \%(\mathrm{v} / \mathrm{v})$ bovine calf serum. Powdered MEM containing non-essential amino acids was reconstituted in glass-distilled water. Sodium succinate, succinic acid and choline bitartarate were added to $0.5,0.5$ and $0.007 \mathrm{mM}$, respectively (Yamane $e$ t al., 1968), and the medium was sterilized by autoclaving. Glutamine and serum were added after neutralization of the medium with sterile $\mathrm{NaHCO}_{3}$ solution. This sterilization process was economical and had no deleterious effect on cell or chlamydial growth. As has been found by most workers, it was crucial to screen different lots of bovine calf serum for suitability for chlamydial replication. Several clones of $\mathrm{HeLa} 229$ were isolated by plating 100 to 200 cells in a $15 \mathrm{~cm}$ diameter dish, and after $7 \mathrm{~d}$ at $37^{\circ} \mathrm{C}$ removing the cells by trypsinization within a stainless steel cylinder placed over well-separated colonies. Each of the clones was tested for chlamydial adherence and replication. The work described here was done with one clonal isolate found to be superior in supporting the replication of $C$. trachomatis UW-31 and LGV440.

McCoy cells were from Whittaker/MA Bioproducts, Walkersville, Md. Clones were isolated as described for HeLa cells. The results reported here were obtained using a clonal isolate.

Chlamydiae. C. trachomatis UW-31 serotype K was grown in HeLa 229 or McCoy cells in the presence of cycloheximide $\left(1 \mu \mathrm{g} \mathrm{ml}^{-1}\right)$ as described previously (Bose et al., 1983). C. trachomatis LGV440 serotype L1 was purchased from the American Type Culture Collection and was grown in HeLa 229 or McCoy cells. Samples of chlamydia-containing cells were stored at $-80^{\circ} \mathrm{C}$. No bacterial contamination was detected after streaking blood agar plates.

Preparation of radioactively labelled chlamydiae. The cycloheximide-containing chlamydial growth medium was removed 20 to $22 \mathrm{~h}$ after infection with LGV 440 and $46 \mathrm{~h}$ after infection with UW-31, and replaced with $20 \mathrm{ml}$ labelling medium per NUNC $175 \mathrm{~cm}^{2}$ flask. For labelling with ${ }^{32} \mathrm{P}$, the medium contained $10 \%$ of the normal amount of inorganic phosphate which allowed extensive labelling with approximately $50 \%$ chlamydial yield. Usually 0.5 to $\mathrm{I} \mathrm{mCi}{ }^{32} \mathrm{P}$ per flask was added. For labelling with $\left[5,6{ }^{-} \mathrm{H}\right]$ uridine $\left(25 \mu \mathrm{Ci} \mathrm{ml}^{-1} ; 925 \mathrm{kBq} \mathrm{ml}^{-1}\right)$, regular chlamydial growth medium was used. Reticulate body-free EBs were obtained by velocity sedimentation of filtered samples through a linear 10 to $40 \%$ sucrose gradient (Bose \& Paul, 1982). After concentration by sedimentation of the EB-containing fractions, samples were quick-frozen and stored at $-80^{\circ} \mathrm{C}$.

Chlamydial adherence assay. Monolayer cultures of HeLa 229 or McCoy cells were established by plating $3 \times 10^{5}$ HeLa or $4 \times 10^{5} \mathrm{McCoy}$ cells in 4- or 24-well NUNC multidishes $\left(2 \mathrm{~cm}^{2}\right.$ growth area) and incubating them for 22 to $24 \mathrm{~h}$ at $37^{\circ} \mathrm{C}$. The growth medium was aspirated and the cultures were washed twice with $500 \mu \mathrm{l}$ Earle's balanced salt solution buffered with $15 \mathrm{~mm}$-HEPES, $\mathrm{pH} 7 \cdot 2$, (EH) per well. The temperature of EH was equilibrated to either $5{ }^{\circ} \mathrm{C}$ or $37^{\circ} \mathrm{C}$, depending on the temperature of subsequent incubation of the chlamydiae with cells. Labelled EBs were then added to the lectin- or sugar-treated cultures (see below) to a final volume of $200 \mu 1$. After incubation with rocking of the dishes at maximum speed (Bellco rocker) for $30 \mathrm{~min}$, the reactions were terminated by aspiration and washing of the monolayers five times with phosphate-buffered saline (PBS; $0.14 \mathrm{M}-\mathrm{NaCl}$ containing $10 \mathrm{mM}$-sodium phosphate buffer, $\mathrm{pH} 7.2$ ) to remove the unattached EBs. To each well, $150 \mu \mathrm{l}$ PBS containing $1 \mathrm{mM}$-EDTA or containing, in addition, GlcNAc at $10 \mathrm{mg} \mathrm{ml}^{-1}$ (to prevent lectin-induced aggregation of cells) was added and the cells were detached by scraping with a rubber policeman attached to a flexible drill shaft connected to a foot-switch-operated electric motor. After thorough resuspension, $100 \mu \mathrm{l}$ was removed for radioactivity counting by liquid scintillation spectrometry, and $5 \mu \mathrm{l}$ was used for cell counting in a Royco particle counter with a $95 \mu \mathrm{m}$ orifice. The cell-associated radioactivities, measured at least twice, were normalized for cell number to correct for variable cell losses that occur after certain treatments. Thus, the adherence rates reported here are based on radioactivity per $10^{5}$ cells per 30 or 60 min incubation at various temperatures. Every assay was done in duplicate and each experiment was repeated at least three times.

Treatment of HeLa 229 and McCoy cells. Wheat germ agglutinin (WGA) in EH was added to the monolayer cultures and incubated at the desired temperature for $30 \mathrm{~min}$ before the addition of EBs. Longer treatment did not alter the effect on the adherence rate; sometimes the longer treatment resulted in the complete or partial detachment of the monolayer, producing an apparent inhibition of chlamydial adherence, unless corrected for cell number as described above. In some experiments, the lectin was removed before the addition of EBs. 
For treatment with hexoses, washed monolayers were incubated with the reagents dissolved in $\mathrm{EH}$, for $60 \mathrm{~min}$. The sugars were aspirated before the addition of labelled EB suspension.

Inclusion assay. The inclusion-forming ability of UW-31 chlamydiae was assessed using monolayers treated with DEAE-dextran (HeLa cells) or polylysine (McCoy cells, because of toxicity of DEAE-dextran) in 8- or 4-chamber Lab-Tek tissue culture slides (Bose et al., 1983). Polycation treatment was unnecessary for LGV440.

Affinity chromatography on WGA-agarose column. $\left[{ }^{3} \mathrm{H}\right]$ Uridine- or $\left[{ }^{3} \mathrm{H}\right]$ cytidine-labelled purified EBs $(200 \mu \mathrm{l})$, grown in HeLa 229 or McCoy cells, were applied to a $1 \mathrm{ml}$ column $(0.7 \times 2.8 \mathrm{~cm})$ of WGA-agarose $(3 \mathrm{to} 5 \mathrm{mg}$ purified WGA per $\mathrm{ml}$ settled beads), previously equilibrated with PBS containing $10 \mathrm{~mm}-\mathrm{CaCl}_{2}, 0 \cdot 4 \mathrm{mM}-\mathrm{MgSO}_{4}$, $3 \mathrm{mM}-\mathrm{NaN}_{3}$ and $200 \mathrm{mM}$-sucrose (equilibration buffer). The sample was allowed to absorb at room temperature for $15 \mathrm{~min}$ and then the column was washed with the equilibration buffer until the effluent had background radioactivity $(30 \mathrm{ml})$. The column was eluted with $0.2 \mathrm{M}-\mathrm{GlcNAc}$ in the equilibration buffer at a flow rate of $1.5 \mathrm{ml} \mathrm{h}^{-1}$. Fractions $(1 \mathrm{ml})$ were collected and the radioactivity was determined. Columns were regenerated after residual radioactivity was eluted with buffer containing $0 \cdot 1 \%$ Triton X-100 and finally with $300 \mathrm{ml}$ equilibration buffer.

Calculation of adherence rates. Cell-associated radioactivities per culture, cell number per culture, radioactivities per $10^{5}$ cells and rates relative to the control were calculated using the spreadsheet program of Appleworks (Apple Computers, Cupertino, Calif.) and an Apple IIe microcomputer. Graphics were generated using the Analytical Graphics program (Scientific Software Products, Inc., Indianapolis, Ind.). The data were statistically analysed to obtain means, standard deviations and $P$ values by a 2 -tail $t$-test in a commercial statistics package.

Reagents. WGA and WGA-agarose beads were from E. Y. Laboratories. Trypsin, $N$-acetylglucosamine, $N, N^{\prime}-$ diacetylchitobiose, $N$-acetylgalactosamine, $N$-acetylneuraminic acid, succinic acid, sodium succinate, cycloheximide, sodium azide, glutamine and choline bitartarate were from Sigma. HEPES and gentamicin were from United States Biochemical Corp. Polycarbonate membrane filters $(0.6 \mu \mathrm{m}$ pore size) were from Nuclepore Corp. Density-gradient grade sucrose was purchased from Schwarz/Mann Biotech. Radioactive chemicals were from ICN Radiochemicals. Powdered medium and bovine calf serum were from Irvine Scientific.

\section{RESULTS}

\section{General characteristics of chlamydial adherence}

The rate of adherence of purified EBs of $C$. trachomatis UW-31(K), a non-LGV serovar, remained linear with time for no longer than $75 \mathrm{~min}$, either at $5^{\circ} \mathrm{C}$ or at $37^{\circ} \mathrm{C} \mathrm{(Fig.} \mathrm{1).} \mathrm{Exposure}$ of the EBs to heat $\left(60^{\circ} \mathrm{C}, 5 \mathrm{~min}\right)$ resulted in a dramatic reduction of the adherence to HeLa 229 cultures, but only at $5{ }^{\circ} \mathrm{C}$. The adherence rate of heated EBs at $37^{\circ} \mathrm{C}$ was slightly stimulated relative to that of unheated $\mathrm{EBs}$, a phenomenon that was noted with another non-LGV serovar, G17(A), of C. trachomatis (Lee, 1981). We did not detect any inclusion-forming activity in the heated samples (data not shown). The studies reported here involve incubation periods not exceeding $60 \mathrm{~min}$ beyond which adherence rates do not remain linear.

Unlike the positive cooperativity of adherence exhibited by UW-31 (Bose \& Smith, 1984), LGV440 showed Michaelis-Menten type kinetics of adherence to HeLa 229 cultures with varying chlamydial input (data not shown). Addition of unlabelled EBs also did not enhance the adherence rate of labelled LGV440 at low input, in contrast to the observations with UW-31 (Bose \& Smith, 1984).

\section{Effect of WGA treatment on the adherence rate of LGV440}

HeLa cell-grown chlamydiae. We had previously reported that the adherence of two LGV serovars, 434(L2) and 404(L3), to HeLa 229 was unaffected by WGA (Bose \& Paul, 1982), while that of UW-31(K) was enhanced in the absence of the stimulator of adherence, DEAE-dextran (Bose et al., 1983). Data summarized in Table 1 show that the adherence of LGV440 grown in HeLa cells was stimulated by WGA. Adherence at $5^{\circ} \mathrm{C}$ was stimulated approximately twofold

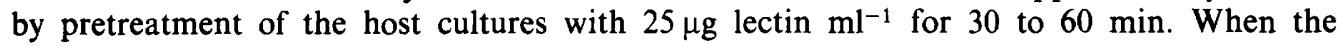
temperature of the assay was $37^{\circ} \mathrm{C}$, at which both attachment and endocytosis of the bound EBs occur (Byrne, 1978; Soderlund \& Kihlstrom, 1983), the stimulatory effect was not observed. Assuming that the observed stimulation was caused by a lectin-mediated adherence, i.e. lectin bound to the HeLa cell surface providing additional attachment sites for the EB (Bose et al., 1983; Bose \& Smith, 1984), and that at $37^{\circ} \mathrm{C}$ cell-bound WGA was internalized (Kramer \& Canellakis, 1975), cultures were treated with the respiratory inhibitor sodium azide, and the 


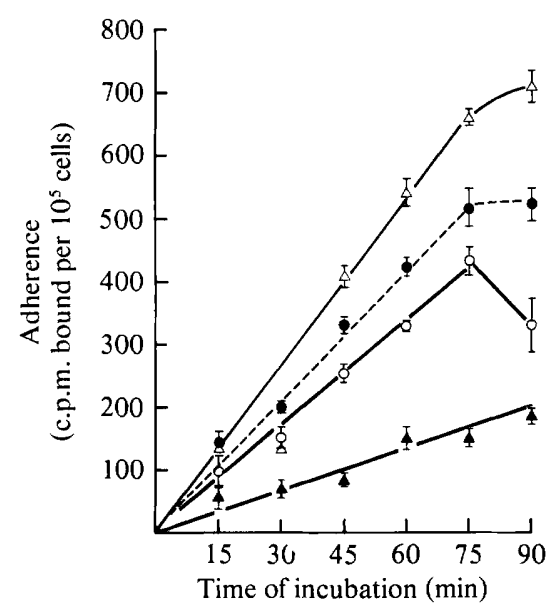

Fig. 1. Kinetics of adherence of ${ }^{32} \mathrm{P}$-labelled purified C. trachomatis UW-31 to monolayers of HeLa 229 cells. Cell-associated radioactivity was determined in duplicate $2 \mathrm{~cm}^{2}$ wells (NUNC) after incubation at $5^{\circ} \mathrm{C}(\triangle)$ or $37^{\circ} \mathrm{C}(\mathrm{O})$. Adherence of a suspension of EBs heated at $60^{\circ} \mathrm{C}$ for $5 \mathrm{~min}$ before adding to the monolayers is shown by the filled symbols. Points represent the mean of duplicate samples \pm SD. The experiment was done four times.

Table 1. Effect of pretreatment with WGA of HeLa 229 cells on subsequent adherence of LGV440 grown in HeLa 229 cells

Chlamydiae were passaged eight times in HeLa 229 cells before the preparation of ${ }^{32} \mathrm{P}$-labelled EBs. HeLa 229 monolayers for the adherence assay were prepared by plating $3 \times 10^{5}$ cells per $2 \mathrm{~cm}^{2}$ well (NUNC 4-well multidishes) $24 \mathrm{~h}$ before assay. WGA was added to washed monolayers at $25 \mu \mathrm{g} \mathrm{ml}^{-1}$ and cells were incubated at $5{ }^{\circ} \mathrm{C}$ for various periods. The lectin was removed and chlamydial adherence in duplicate wells determined at $5{ }^{\circ} \mathrm{C}$ after $30 \mathrm{~min}$ incubation. The experiment was repeated three times with different preparations of chlamydiae.

$\begin{array}{cccc}\begin{array}{c}\text { Time of treatment } \\ \text { with WGA (min) }\end{array} & \begin{array}{c}\text { Chlamydial adherence* } \\ \text { (c.p.m. per } 10^{5} \text { cells) }\end{array} & \begin{array}{c}\text { Percentage } \\ \text { of control }\end{array} & P \text {-value } \dagger \\ \text { Untreated } & 278 \pm 12 & 100 & - \\ 0 & 408 \pm 4 & 147 & 0 \cdot 191 \\ 30 & 520 \pm 18 & 187 & 0 \cdot 013 \\ 60 & 539 \pm 38 & 194 & 0 \cdot 044 \\ 120 & 401 \pm 34 & 144 & 0 \cdot 081 \\ & & \end{array}$

effect of WGA on the adherence of LGV440 was measured at $37^{\circ} \mathrm{C}$. Lectin-dependent stimulation was observed only in the azide-treated cultures at this temperature (Table 2). Similar results were obtained with HeLa cultures pretreated with cyanide and WGA (data not shown), indicating that, by preventing endocytosis of WGA, the respiratory inhibitors allowed the cellsurface-bound lectin to be accessible for chlamydial adherence at $37^{\circ} \mathrm{C}$.

McCoy cell-grown chlamydiae. The stimulatory effect of WGA on the adherence of LGV440 was not observed by Levy (1979) or by Soderlund \& Kihlstrom (1983). In those studies, LGV440 was grown in L and McCoy cells, respectively. Both are of murine origin. To test the probability that the EBs acquired unique surface-associated ligands (adhesins) during growth in human or mouse cell lines, LGV440 and UW-31(K) were passaged in McCoy cultures. After 8 to 10 passages, labelled EBs were prepared in McCoy cells and their behaviour towards WGA was studied. 
Table 2. Effect of sodium azide on the adherence of LGV440(L1) to WGA-treated HeLa monolayers at $37^{\circ} \mathrm{C}$

Sodium azide ( $5 \mathrm{~mm}$ ) was added to HeLa 229 monolayers in 24-well NUNC multidishes. After 15 min at $37^{\circ} \mathrm{C}$, WGA and/or $\mathrm{NaN}_{3}$ were added to $20 \mu \mathrm{g} \mathrm{ml}^{-1}$ and $5 \mathrm{~mm}$ respectively. After a further $15 \mathrm{~min}$, ${ }^{32} \mathrm{P}$-labelled EBs of LGV440 were added without removing the reagents and allowed to interact with the monolayers for $30 \mathrm{~min}$ at $37^{\circ} \mathrm{C}$. The experiment was repeated three times with different preparations of chlamydiae.

$\begin{array}{lccc}\text { Treatment } & \begin{array}{c}\text { Chlamydial uptake* } \\ \text { (c.p.m. per } 10^{5} \text { cells) }\end{array} & \begin{array}{c}\text { Percentage } \\ \text { of control }\end{array} & \begin{array}{c}P \text {-value relative } \\ \text { to control } \dagger\end{array} \\ \text { None } & 401 \pm 8 & 100 & - \\ \mathrm{WGA} & 422 \pm 12 & 105 & 0 \cdot 397 \\ \mathrm{NaN}_{3} & 257 \pm 40 & 64 & 0 \cdot 102 \\ \mathrm{NaN}_{3}+\text { WGA } & 718 \pm 8 & 179 & 0 \cdot 016 \\ & & & \\ & \text { * Mean } \pm \text { SD of duplicate samples. } & \\ & + \text { Determined by a 2-tail } t \text {-test. }\end{array}$

Table 3. Effect of chlamydial passage in HeLa 229 and McCoy cells on the WGA-mediated
adherence of purified EBs to different cell lines

UW-31(K) was passaged 15 times in HeLa 229 and 8 times in McCoy cell monolayers before the preparation of $\left[5,6^{-3} \mathrm{H}\right]$ uridine-labelled EBs. Lectin was added to the test cell lines 15 min before the initiation of the adherence assay at $5{ }^{\circ} \mathrm{C}$ for $30 \mathrm{~min}$ and was present during the incubation. LGV440(Ll) was passaged 12 times in HeLa 229 and 8 times in McCoy cell cultures before the preparation of [5,6${ }^{3} \mathrm{H}$ ]uridine-labelled EBs. The adherence assay was at $5{ }^{\circ} \mathrm{C}$ for $60 \mathrm{~min}$. Similar results were obtained in six other experiments with HeLa cell-grown chlamydiae and in three others with McCoy cell-grown chlamydiae.

\begin{tabular}{|c|c|c|c|c|c|c|}
\hline \multirow{3}{*}{$\begin{array}{c}\text { Chlamydial } \\
\text { strain }\end{array}$} & \multirow{3}{*}{$\begin{array}{l}\text { Addition } \\
\left(\mu \mathrm{g} \mathrm{ml}^{-1}\right)\end{array}$} & & \multicolumn{4}{|c|}{ Adherence (c.p.m. per $10^{5}$ cells)* } \\
\hline & & Host . . & \multicolumn{2}{|c|}{ HeLa } & \multicolumn{2}{|c|}{ McCoy } \\
\hline & & Test cell line . & $\mathrm{HeLa}$ & McCoy & HeLa & McCoy \\
\hline UW-31(K) & $\begin{array}{l}\text { None } \\
\text { WGA (20) } \\
\text { Heated EB }\end{array}$ & & $\begin{array}{r}99 \pm 6 \\
178 \pm 13 \\
40 \pm 1\end{array}$ & $\begin{array}{r}196 \pm 8 \\
167 \pm 15 \\
79 \pm 1\end{array}$ & $\begin{array}{l}222 \pm 3 \\
331 \pm 4 \\
123 \pm 2\end{array}$ & $\begin{array}{l}512 \pm 77 \\
464 \pm 17 \\
230 \pm 10\end{array}$ \\
\hline LGV440(L1) & $\begin{array}{l}\text { None } \\
\text { WGA (10) }\end{array}$ & & $\begin{array}{l}156 \pm 4 \\
293 \pm 18\end{array}$ & $\begin{array}{l}313 \pm 12 \\
547 \pm 3\end{array}$ & $\begin{array}{l}154 \pm 1 \\
156 \pm 5\end{array}$ & $\begin{array}{l}385 \pm 60 \\
410 \pm 53\end{array}$ \\
\hline
\end{tabular}

* Mean \pm SD of duplicate wells.

Data summarized in Table 3 are representative of about 100 experiments with $C$. trachomatis UW-31(K) and 20 with LGV440 passaged in HeLa 229, and of about 10 experiments using chlamydiae passaged in McCoy monolayers. UW-31 grown in HeLa 229 or in McCoy cells showed characteristic enhancement of adherence by WGA; with $20 \mu \mathrm{g} \mathrm{WGA} \mathrm{ml}^{-1}$, adherence of purified EBs was stimulated 1.79-fold; with $50 \mu \mathrm{g} \mathrm{ml}^{-1}$, a $2 \cdot 2$-fold increase was observed (data not shown). No enhancement or inhibition by the lectin occurred in McCoy cells. With UW-31 grown in McCoy cells WGA produced stimulation in HeLa cells but not in McCoy cells.

The passage history of LGV440 appeared to determine its adherence characteristics. LGV440 grown in HeLa cells showed WGA-enhanced binding to HeLa as well as McCoy monolayers at $5^{\circ} \mathrm{C}$. On the other hand, after eight passages in McCoy cells, adherence of this serotype of $C$. trachomatis to either cell line was not affected by WGA (Table 3). Both serovars of the chlamydiae showed increased adherence on a per cell basis to McCoy cells.

The inclusion-forming ability in HeLa monolayers of LGV440 grown in HeLa cells or McCoy cells was stimulated by WGA in the expected manner. More than two-fold enhancement $(P<$ 0.001 ) by WGA was seen with HeLa cell-grown but not with McCoy cell-grown chlamydiae (Table 4), thus reinforcing the adherence data. 
Table 4. Effect of WGA on the infectivity of LGV440 grown in HeLa or McCoy cells

HeLa 229 cells were plated in 8-chamber Lab-Tek tissue-culture slides. After $24 \mathrm{~h}$ at $37^{\circ} \mathrm{C}$, twicewashed monolayers were treated with $2 \mu \mathrm{g} \mathrm{WGA} \mathrm{ml}^{-1}$ for $10 \mathrm{~min}$ at $22^{\circ} \mathrm{C}$. After removal of the lectin, the monolayers were infected with appropriately diluted chlamydial inoculum. After adsorption at $5^{\circ} \mathrm{C}$ for $30 \mathrm{~min}$ and incubation at $37^{\circ} \mathrm{C}$ for an additional $30 \mathrm{~min}$, the inoculum was aspirated and each chamber received $400 \mu \mathrm{l}$ growth medium containing cycloheximide $\left(1 \mu \mathrm{g} \mathrm{ml}^{-1}\right)$. Giemsa-stained inclusions were counted after $42 \mathrm{~h}$ incubation at $37^{\circ} \mathrm{C}$. Similar data were obtained with three separate experiments.

$\begin{array}{rlrc}\begin{array}{c}\text { Source of } \\ \text { LGV440 }\end{array} & \text { Treatment } & \begin{array}{r}\text { Inclusions } \\ \text { per field* }\end{array} & \begin{array}{c}\text { Treated/ } \\ \text { untreated }\end{array} \\ \text { HeLa 229 } & \text { None } & 8 \pm 1.41 & 1 \\ & \text { WGA } & 18 \pm 0.75 & 2.3 \\ \text { McCoy } & \text { None } & 20 \pm 3.26 & 1 \\ & \text { WGA } & 17.2 \pm 1.6 & 0.85\end{array}$

Table 5. Effect of hexoses on the adherence of LGV440 grown in HeLa cells

HeLa and McCoy monolayers in 24-well multidishes were treated with the sugars for 60 min at $37^{\circ} \mathrm{C}$. After removal of the reagents, adherence of $\left[{ }^{3} \mathrm{H}\right]$ uridine-labelled EBs was measured at $5^{\circ} \mathrm{C}$ for $30 \mathrm{~min}$. The experiment was repeated three times with similar results.

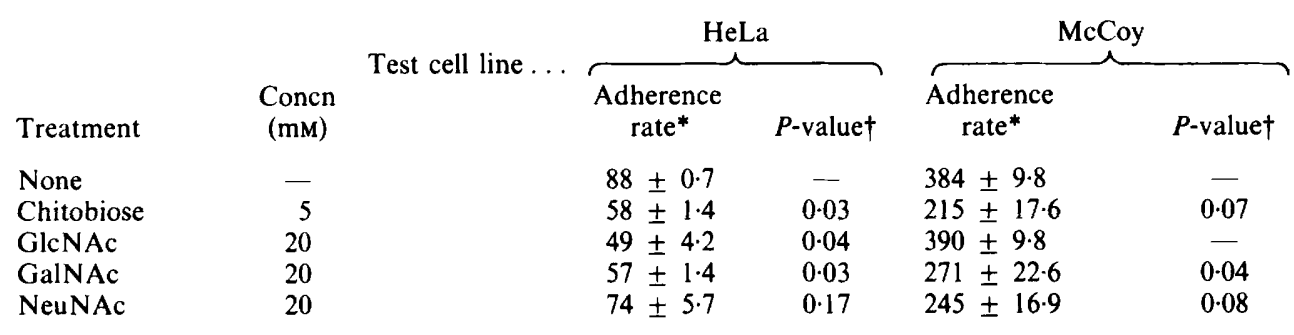

* C.p.m. bound per $10^{5}$ cells; mean \pm SD of duplicate samples.

$\dagger P$-values relative to untreated control cultures, calculated by a 2 -tail $t$-test.

Table 6. Effect of hexoses on the adherence of LGV440 grown in McCoy cells

Conditions were identical to the experiment summarized in Table 5. The experiment was repeated three times with similar results.

$\begin{array}{lccccc}\text { Treatment } & \begin{array}{c}\text { Concn } \\ (\mathrm{mM})\end{array} & \text { Test cell line } \ldots & \overbrace{\begin{array}{c}\text { Adherence } \\ \text { rate }^{*}\end{array}}^{\text {P-value } \dagger} & \overbrace{\begin{array}{c}\text { Adherence } \\ \text { rate }^{*}\end{array}}^{\text {MeCoy }} \\ \text { None } & - & 87 \pm 4.9 & - & 244 \pm 2.8 & - \\ \text { Chitobiose } & 5 & 89 \pm 2.1 & 0.50 & 211 \pm 7.0 & 0.057 \\ \text { GlcNAc } & 20 & 72 \pm 8.5 & 0.11 & 254 \pm 0.7 & 0.172 \\ \text { GalNAc } & 20 & 86 \pm 33 & - & 201 \pm 3.5 & 0.01 \\ \text { NeuNAc } & 20 & 95 \pm 7.7 & 0.16 & 211 \pm 14.1 & 0.16\end{array}$

* C.p.m. bound per $10^{5}$ cells; mean \pm SD of duplicate samples.

$\dagger P$-values relative to untreated control cultures, calculated as described in Table 5. 


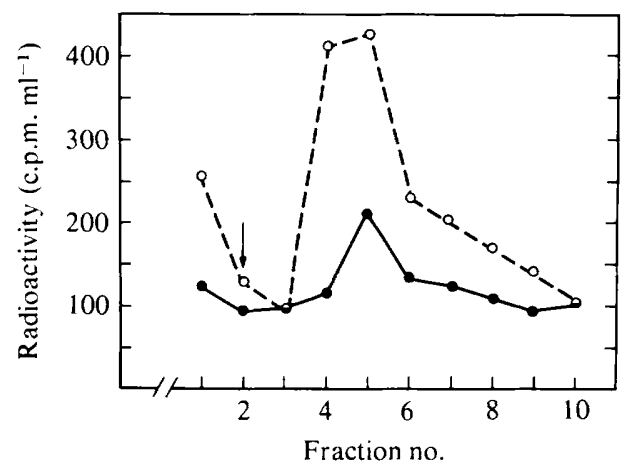

Fig. 2. Affinity chromatography on WGA-agarose columns of $C$. trachomatis LGV440 grown in HeLa and McCoy cells. Chlamydiae were grown in HeLa 229 (O) or McCoy (O) cell monolayers, labelled during growth with $\left[5,6^{-3} \mathrm{H}\right]$ cytidine $\left(25 \mu \mathrm{Ci} \mathrm{ml}^{-1}\right)$ and the EBs were purified. Each sample contained 2 $\times 10^{4}$ c.p.m. Details of chromatography are given in Methods. The arrow indicates when elution with buffer containing $0.2 \mathrm{M}-$ GlcNAc was begun. The experiment was repeated seven times using two different lots of WGA-gel.

LGV440 grown in HeLa cells and passaged once in McCoy cells, or grown in McCoy cells and passaged once in HeLa cells, retained their characteristic response to WGA (data not shown). In other words, acquisition of WGA-mediated or WGA-independent adherence required at least six to eight passages, unlike the infectivity patterns observed with C. psittaci GPIC (Allan \& Pearce, $1979 a, b)$.

Affinity chromatography on WGA-agarose of LGV440 EBs grown in HeLa cells and McCoy cells

To determine if growth of $C$. trachomatis LGV440 in HeLa or in McCoy cells resulted in alterations in the surface of the EBs such that the lectin WGA reacted with HeLa cell-grown but not with McCoy cell-grown chlamydiae, we purified EBs labelled with $\left[{ }^{3} \mathrm{H}\right]$ cytidine during growth in HeLa or in McCoy cell monolayers, and chromatographed them on a column of WGA-agarose. With HeLa cell-grown EBs, $50 \%$ of the applied radioactivity $\left(2 \times 10^{4}\right.$ c.p.m. $)$ in $2 \mu \mathrm{g}$ protein bound to the lectin gel, and $18 \%$ was eluted with $0.2 \mathrm{M}$-GlcNAc-containing buffer (Fig. 2). However, only about $15 \%$ of McCoy cell-grown EBs $\left(2 \times 10^{4}\right.$ c.p.m. in $3 \mu$ g protein) bound to the lectin gel, $9 \%$ being eluted by GlcNAc-containing buffer. No labelled material was released with buffer containing $0.4 \mathrm{M}$-GlcNAc. Only with $0.1 \%$ Triton X-100 in $0.4 \mathrm{M}$-GlcNAccontaining buffer was residual radioactivity quantitatively eluted (data not shown). These results show that $C$. trachomatis LGV440 grown in HeLa cells was capable of binding to WGA and could be partially eluted with the lectin-specific sugar GlcNAc. Quantitatively less binding to the affinity gel occurred when the chlamydiae were passaged in McCoy cells.

Effect of sugars on the adherence of LG440 EBs grown in HeLa cells and McCoy cells

Stimulation by WGA of HeLa cell-grown EBs but not of McCoy cell-grown EBs suggested that the adherence of the former should be sensitive to the lectin-specific hexoses. Data summarized in Table 5 indicate that this was the case. As previously observed with $C$. trachomatis UW-31 (Bose et al., 1983), GlcNAc, GalNAc, and additionally the disaccharide chitobiose, interfered with the adherence of HeLa cell-grown LGV440 to HeLa monolayers ( $P$ $<0.001$ ). In McCoy cell monolayers, chitobiose, GalNAc and NeuNAc inhibited but GlcNAc failed to interfere with the adherence. Inhibition by hexoses was not detected when chlamydial uptake was assayed at $37^{\circ} \mathrm{C}$, a situation that we had previously noted with the adherence of UW-31 to HeLa cells (Bose et al., 1983). When purified EBs were obtained from McCoy cell cultures, none of the sugars influenced the adherence to either test cell line (Table 6). The 15 to $18 \%$ inhibition was not considered significant in these assays. Soderlund \& Kihlstrom (1983) found that LGV440, preincubated with chitobiose, became markedly diminished in its ability to adhere to McCoy cells. Other sugars had no effect. 


\section{DISCUSSION}

Early work with growth of $C$. trachomatis in mammalian cell cultures recorded a gradual adaptation of the yolk-sac-grown isolates (Collier, 1962; Mitsui et al., 1967). No detectable change was apparent in the antigenic properties of cell-culture-adapted chlamydiae (Gordon et al., 1971). Allan \& Pearce $(1979 a)$ were the first to observe acquisition of stable infectivity properties by a single passage of egg-grown $C$. psittaci GPIC in McCoy cultures. Not only did the unassisted adherence of $C$. psittaci GPIC to monolayers increase after a single passage of the yolk-sac-grown organisms, but this acquired infectivity was lost by growth of the cell-grown organisms in eggs. Further, yolk-sac-grown GPIC appeared to have an egg-derived antigen that played a major role in the unassisted infection of McCoy cells (Allan \& Pearce, 1979b). Differences due to chlamydial host have been noted in the sedimentation properties of EBs of $C$. psittaci 6BC (Kordova et al., 1977; Neuman et al., 1980), in the lysosomal stability of mouse macrophages (Kordova et al., 1972a) and L cells (Kordova et al., 1972b) infected with C.psittaci $6 \mathrm{BC}$, and in the cytotoxic changes produced in the infected cells.

We were unable to detect an inhibition of adherence by the lectin WGA noted by Levy (1979), and instead demonstrated an enhancement (Bose et al., 1983) that resulted in the change from positive cooperativity of adherence to a first order reaction (Bose \& Smith, 1984). Both Levy (1979) and, more recently, Soderlund \& Kihlstrom (1983) propagated $C$. psittaci 6BC and $C$. trachomatis LGV440 in mouse L and McCoy cells respectively, and noted interference of chlamydial adherence by WGA. It was clear from the results in Tables 1 and 4, that WGA stimulated the adherence and infectivity of EBs of C. trachomatis grown in HeLa 229 cells. The complexity of chlamydial interaction became apparent when one examined the behaviour of the two serovars, UW-31(K) and LGV440(L1). The non-LGV serovar UW-31, whether passaged in McCoy or in HeLa cells, exhibited WGA stimulation but only in HeLa 229 as the test cell line (Table 3). That it was not an inability of McCoy cells to bind WGA was shown by $C$. trachomatis LGV440 passaged in HeLa 229 cells, where the lectin stimulated chlamydial adherence in both cell lines. Soderlund \& Kihlstrom (1983), using labelled WGA, demonstrated lectin binding to McCoy cells. In our hands, WGA induced aggregation of both HeLa 229 and McCoy cells, which was prevented by the specific sugar GlcNAc, indicating the presence of WGA receptors on the cell surface.

Affinity chromatography on WGA-agarose columns also indicated a difference, at least quantitative, between LGV440 grown in HeLa cells and McCoy cells (Fig. 2). Quantitative elution of the labelled EBs was effected only with $0.1 \%$ Triton X-100, suggesting that the EB samples might have lysed, releasing labelled material that bound tightly to the gel, even in the presence of $200 \mathrm{~mm}$-sucrose in the buffer. The ability of GalNAc and chitobiose to inhibit the adherence of LGV440 grown in HeLa cells to both HeLa and McCoy cells, and the differential inhibition by GlcNAc (HeLa only) and NeuNAc (McCoy only) suggests complex interactions, eluding simple generalizations.

Fig. 1 provides further evidence for the heterogeneity of chlamydial ligands responsible for adherence. Confirming the observation with another non-LGV serovar, G17(A) (Lee, 1981), it was clear that the adherence of heated EBs was not inhibited, but was slightly greater than that of unheated EBs. However, this was observed only at $37^{\circ} \mathrm{C}$, a temperature also used by Lee (1981). When the adherence was assayed at $5^{\circ} \mathrm{C}$, adherence of heated UW-31 was markedly reduced. One interpretation of this phenomenon was that the non-LGV chlamydial EBs have both heat-labile and heat-stable ligands, discernible by varying the temperature of the adherence assay. The presumptive heat-labile ligands (adhesins) should be the ones sensitive to the amino sugars, since the latter are innocuous at $37^{\circ} \mathrm{C}$. We had noted earlier that the inhibition of adherence of UW-31 due to neuraminidase treatment of HeLa cultures decreased with the storage of chlamydial preparation, while other properties such as adherence rate and the WGA effects remained stable (Bose et al., 1983). Positive cooperativity in the adherence of this serovar to HeLa was also labile to storage (Bose \& Smith, 1984).

The ability to acquire unique surface properties important in mediating attachment to host membrane may have an important role in natural infection. Both polyclonal (Caldwell \& Perry, 1982) and monoclonal (Peeling et al., 1984) antibodies against purified outer membrane protein 
of $C$. trachomatis are capable of neutralizing infectivity, i.e. development of inclusions in in vitro cultures. Monoclonal antibody-treated labelled EBs were not diminished in their adherence to HeLa monolayers (Peeling et al., 1984). The role of serum antibody levels upon in vivo chlamydial infection was not clear. Despite the presence of maternal antibody, the rate of chlamydial conjunctivitis in perinatally infected infants can be as high as $35 \%$ (Schachter et al., 1979). It is not unreasonable to postulate that the intracellular pathogen acquires surface antigens which allow it to escape detection by the host's surveillance system. Experiments are now in progress to detect and identify surface macromolecules of EBs grown in different hosts.

This work was supported by a grant to St Louis University School of Medicine from the US Public Health Service (no. PHS 5 SO7 RR 05388-23).

\section{REFERENCES}

Allan, I. \& Pearce, J. H. (1979a). Host modification of chlamydiae: differential infectivity for cell monolayers of chlamydiae grown in eggs and monolayers. Journal of General Microbiology 112, 53-59.

Allan, I. \& Pearce, J. H. (1979b). Host modification of chlamydiae: presence of an egg antigen on the surface of chlamydiae grown in the chick embryo. Journal of General Microbiology 112, 61-66.

Bose, S. K. \& Paul, R. G. (1982). Purification of Chlamydia trachomatis lymphogranuloma venereum elementary bodies and their interaction with HeLa cells. Journal of General Microbiology 128, 13711379.

Bose, S. K. \& SMIth, G. B. (1984). Positive cooperativity in the adherence between elementary bodies of Chlamydia trachomatis strain UW-31 and HeLa cells. FEMS Microbiology Letters 23, 55-58.

Bose, S. K., Smith, G. B. \& Paul, R. G. (1983). Influence of lectins, hexoses, and neuraminidase on the association of purified elementary bodies of Chlamydia trachomatis UW-31 with $\mathrm{HeLa}$ cells. Infection and Immunity 40, 1060-1067.

BYRNE, G. I. (1978). Kinetics of phagocytosis of Chlamydia psittaci by mouse fibroblasts ( $\mathrm{L}$ cells): separation of the attachment and ingestion stages. Infection and Immunity 19, 607-612.

Caldwell, H. D. \& Perry, L. J. (1982). Neutralization of Chlamydia trachomatis infectivity with antibodies to the major outer membrane protein. Infection and Immunity 38, 745-754.

Collier, L. H. (1962). Growth characteristics of inclusion blenorrhea virus in cell cultures. Annals of the New York Academy of Sciences 98, 42-49.

Gordon, F. B., Nichols, R. L. \& QuaN, A. L. (1971). Immunotyping of Chlamydia trachomatis with fluorescent antibody: retention of immunospecificity in cell culture passage, and typing with infected cell monolayers. In Trachoma and Related Disorders, pp. 358-362. Edited by R. L. Nichols. Amsterdam: Excerpta Medica.

Griffiths, M. S., Ainsworth, S. \& Pearce, J. H. (1976). Infectivity titration of guinea-pig inclusion conjunctivitis agent in irradiated McCoy cells. Journal of General Microbiology 95, 249-256.

JENKIN, H. M. (1966). The continuous passage of agents of trachoma in cell culture. I. Characteristics of TW-3 and BOUR strains of trachoma cultivated in serial passage in HeLa 229 cells. Journal of Infectious Diseases 116, 390-399.

Kordova, N., Poffenroth, L. \& Wilt, J. C. (1972a). Lysosomes and the 'toxicity' of Rickettsiales. II.
Non-cytocidal interactions of egg-grown $C$. psittaci $6 \mathrm{BC}$ and in vitro macrophages. Canadian Journal of Microbiology 18, 869-873.

Kordova, N. Poffenroth, L. \& WilT, J. C. (1972b). Lysosomes and the 'toxicity' of Rickettsiales. III. Response of $\mathrm{L}$ cells infected with egg-attenuated $C$. psittaci 6BC strain. Canadian Journal of Microbiology 18, 1343-1348.

Kordova, N., Martin, C., Wilt, J. C. \& Neuman, M. (1977). Sucrose density differences of Chlamydia psittaci 6BC in relation to its host. Canadian Journal of Microbiology 23, 649-652.

Kramer, R. H. \& Canellakis, E. S. (1979). The surface glycoproteins of the HeLa cell. Internalization of wheat germ agglutinin-receptors. Biochimica et biophysica acta 551, 328-348.

LEE, C. K. (1981). Interaction between a trachoma strain of Chlamydia trachomatis and mouse fibroblasts (McCoy cells) in the absence of centrifugation. Infection and Immunity 31, 584-591.

LEVY, N. J. (1979). Wheat germ agglutinin blockage of chlamydial attachment sites: antagonism by $N$ acetyl-D-glucosamine. Infection and Immunity 25, 946-953.

Mitsui, Y., Kitamuro, T. \& Fujimoto, M. (1967). Adaptation of TRIC agents to tissue culture and characteristics of tissue culture adapted variants. American Journal of Ophthalmology 63, 1191-1205.

Neuman, M. R., Kordova, N. \& Wilt, J. C. (1980). Host influence on the density of chlamydiae in Renografin gradients. Zentralblatt für Bakteriologie, Mikrobiologie und Hygiene (Abteilung I, Originale A) 247, 526-529.

Peeling, R., Mclean, I. W. \& Brunham, R. C. (1984). In vitro neutralization of Chlamydia trachomatis with monoclonal antibody to an epitope on the outer membrane protein. Infection and Immunity 46, 484-488.

Schachter, J., Grossman, M., Holt, J., Sweet, R., GoOdIeR, E. \& Mille, J. (1979). Prospective study of chlamydia infection in neonates. Lancet ii, 377 380.

Soderlund, G. \& Kihlstrom, E. (1983). Attachment and internalization of a Chlamydia trachomatis lymphogranuloma venereum strain by McCoy cells: kinetics of infectivity and effect of lectins and carbohydrates. Infection and Immunity 42, 930-935.

Yamane, I., Matsuya, Y. \& Jimbo, K. (1968). An autoclavable powdered culture medium for mammalian cells. Proceedings of the Society for Experimental Biology and Medicine 127, 335-336. 